\title{
Review
}

Acta Cytologica 2019;63:109-117

DOI: $10.1159 / 000493737$
Received: September 12,2018

Accepted after revision: September 13, 2018

Published online: February 22, 2019

\section{Human Papillomavirus and Genital Disease in Men: What We Have Learned from the HIM Study}

\author{
Laura Sichero $^{a} \quad$ Anna R. Giuliano ${ }^{b}$ Luisa Lina Villa ${ }^{a, c}$ \\ ${ }^{a}$ Center for Translational Research in Oncology, Instituto do Cancer do Estado de Sao Paulo, Hospital das Clinicas \\ da Faculdade de Medicina da Universidade de Sao Paulo, São Paulo, Brazil; ${ }^{b}$ Center for Immunization and \\ Infection Research in Cancer, and the Department of Cancer Epidemiology, H. Lee Moffitt Cancer Center and \\ Research Institute, Tampa, FL, USA; ' Department of Radiology and Oncology, Faculdade de Medicina, \\ Universidade de São Paulo, São Paulo, Brazil
}

\section{Keywords}

Cohort study $\cdot \mathrm{HPV} \cdot$ Men $\cdot$ PCR

Abstract

It is currently recognized that in addition to the major impact of human papillomavirus (HPV) infection in females, HPV causes considerable disease in men at the genitals, anal canal, and oropharynx. Specifically, genital HPV infections may progress to genital warts and penile carcinoma. Although studies concerning the natural history of HPV infections and associated neoplasias have mainly focused on women, during the last 2 decades considerable attention has been given in further understanding these infections in men. The HIM (HPV infection in men) Study, the only prospective multicenter study of male HPV natural history, consisted of a large prospective international cohort study in which men from Brazil, the United States, and Mexico were enrolled. The design and protocols of this study allowed unraveling crucial information regarding the relationship between HPV infection and clinical consequences in men, and associated risk factors at each of the anatomic sites where HPV is known to cause cancer in men.

(C) 2019 S. Karger AG, Basel

\section{Introduction}

Human papillomaviruses (HPVs) are non-enveloped, $50 \mathrm{~nm}$ viruses that enclose a circular double stranded DNA of about 8,000 base-pair, physically divided into 3 regions: the early $(\mathrm{E})$ and late $(\mathrm{L})$ regions and the long control region. While E1 and E2 proteins play crucial roles in viral DNA transcription and replication regulation, E4, E5, E6, and $\mathrm{E} 7$ proteins are involved in cell cycle deregulation, immune evasion, and recruitment of replication host factors [1]. L1 and L2 late proteins constitute the major and secondary capsid proteins respectively. Finally, the long control region is a noncoding region that encloses a plethora of cis-elements crucial for viral early transcription and replication regulation [2].

HPVs infect the stratified squamous epithelia, both mucosal and cutaneous, and preferentially target mitotically active cells of the basal layer. The E6 and E7 proteins of oncogenic types of HPV stimulate cell proliferation by interacting directly, in addition to several other cellular proteins, with $\mathrm{p} 53$ and $\mathrm{pRB}$ proteins, respectively, both master regulators of the cell cycle [1]. The consequence is

\section{KARGER}

(C) 2019 S. Karger AG, Basel

E-Mail karger@karger.com

www.karger.com/acy
Prof. Luisa Lina Villa

Faculdade de Medicina da Universidade de São Paulo - FMUSP/FFM

Rua Dr. Ovídio Pires de Campos, 872, 3 Andar, Cerqueira César

São Paulo, SP 05403-911 (Brazil)

E-Mail luisapvilla@gmail.com 
expansion of the life span of infected cells favoring the accumulation of mitotic defects, genomic instability and finally neoplasia development.

HPV sare a heterogeneous group of epitheliotropic viruses that belongs to the Papillomaviridae family [3]. HPVs are classified taxonomically based on nucleotide sequence identity, and by now over 200 types have been fully characterized, most of which cluster phylogenetically within the Alpha ( $\alpha)^{-}$, Beta $(\beta)-$, or Gamma $(\gamma)$-HPV genus [4]. While the majority of $\alpha$-HPVs are mucosal types isolated from the anogenital epithelia, some types of this genus, in addition to all $\beta$ - and $\gamma$-HPVs, are originally designated "cutaneous types." The International Agency for Research on Cancer has classified $13 \alpha$-HPVs as group 1 carcinogens $(-16,-18,-31,-33,-35,-39,-45$, $-51,-52,-56,-58,-59$ and -66$)$, commonly referred to as "high-risk HPVs" (HR-HPVs), among which HPV-16 is undoubtedly the most carcinogenic based in the burden of cancers and cancer precursors lesions associated to this infection [3]. On the other hand, HPVs-6, $-11,-40,-42$, $-43,-44$, and -54 are grouped as "low-risk (LR)-HPVs" due to epidemiological association with benign proliferations such as condylomas acuminata. Nevertheless, while classified as LR, HPV-6 has been identified in several malignancies, including carcinomas of the vagina [5], vulva $[6,7]$, penis [8], tongue [9], cervix $[10,11]$, and tonsils [12].

Although studies concerning the natural history of HPV infections and associated neoplasias have mainly focused women, an increasing interest in further understanding the relationship between HPV and disease in men has emerged during the last 2 decades. In fact, it is recognized that HPV is mostly transmitted sexually, and infection by these viruses is strongly linked to the development of tumors in the cervix, vulva, and vagina in women, cancer of the penis in men, as well as tumors in the anal canal and head and neck (predominantly the oropharynx) in both genders.

\section{HPV-Associated Genital Disease in Men}

HPV infection in the penis is detected in $16-69 \%$ of healthy men depending on the population studied, the anatomical site of sampling, and the laboratory method used for HPV detection and typing [13]. These infections may progress to external genital lesions (EGLs), mostly condyloma acuminata (condyloma or genital warts $[\mathrm{GW}]$ ) and penile intraepithelial neoplasia (PeIN) that are thought to precede penile cancer [14].
GW is a common clinical outcome of HPV infection in males and affects mainly individuals aged 25-29 years, decreasing with age; however, the incidence of condyloma remains relatively high throughout a man's life span [15-20]. LR-HPVs 6 and 11 are the etiologic agents of over $90 \%$ of GWs [3]; however, in approximately onethird of the cases multiple viral types, including coinfection with HR-HPV, are detected [21]. GWs are highly infectious and about $65 \%$ of the individuals who have sex with an infected partner will also develop GWs [22]. Most lesions develop within 2-3 months after an HPV infection [20, 23], and although about $30 \%$ of these warts spontaneously regress, recurrence is common, and therefore, treatment impacts in high medical costs [24, 25]. The HIM Study is the only study to document the high rate of GW recurrence under conditions of careful repeated clinical examinations of men for up to 7 years of follow-up [26]. Additionally, even if GW is a benign condition, not associated with mortality, it is an important cause of psychosocial distress and physical discomfort [27].

Penile cancer is a rare devastating disease that accounts for less than $0.5 \%$ of all cancers in men globally [28], and affects mostly individuals aged 50-70 years [29]. Worldwide, areas with high incidence of cervical cancer also tend to have a high incidence of penile cancer [30]: incidence rates are higher in less developed countries representing up to $10 \%$ of male tumors in some parts of Africa, Asia, and South America, in contrast to the United States and Western Europe in which it represents around $0.4 \%$ of all malignancies [31]. The etiology of penile cancer is multifactorial and several risk factors have been identified, including phimosis, poor hygiene, smoking, and chronic inflammatory states, in addition to early age at first sexual intercourse, high number of sexual partners, lack of condom use and neonatal circumcision, and history of GWs [32, 33]. Furthermore, 50\% of all penile cancers appear to be attributable to HPV infection with HR-HPV-16 being the most commonly detected type [34, 35]. Whether HPV-related penile cancers have an improved survival profile compared with cancers unrelated to HPV infection is still a matter of debate [36].

\section{The HIM (HPV in Men) Study}

With the aim of increasing the knowledge concerning HPV infection in men (HIM), a large prospective international cohort study, the HIM Study, was conducted. This study was unique in comparing the natural history of HPV 
in men from the United States, Mexico, and Brazil representing low- and high-risk countries for penile cancer. This study was funded by the National Institute of Health (NIH-USA) to Anna R Giuliano (H. Lee Moffitt Cancer Center and Research Institute, USA) as the Principal Investigator, with Luisa Lina Villa (Instituto do Cancer do Estado de Sao Paulo, Brazil), and Eduardo Lazcano-Ponce (National Institute of Public Health in Cuernavaca, Mexico) as co-Principal Investigators. Eligibility criteria for participation in the study included (a) ages between 18 and 44 years and another group between 45 and 70; (b) living in South Florida, the United States, Sao Paulo, Brazil, or the State of Morelos, Mexico; (c) no previous diagnosis of penile or anal cancer; (d) no diagnosis of genital or anal warts at admission; (f) not HIV infected or have AIDS at diagnosis; and (e) agreement with the scheduled visits every 6 months planned initially for 4 years.

In Mexico, men were recruited at the Instituto de Medicina y Seguridad Social of the State of Morelos. In Brazil, men were recruited at the Reference Center for Treatment of Sexually Transmitted Diseases and AIDS (CRTAIDS) in São Paulo and from the general population. In the United States, participants came from the University of South Florida and Tampa metropolitan area.

Scheduled visits consisted of filling out a questionnaire, undergoing a clinical examination that included visual inspection of the skin and external genitalia, and the collection of blood sample, mouth wash, and genital (coronal sulcus, penis glands and shaft, and scrotum) and anal canal swabs. In the cases of men presenting EGLs, tissue samples were further collected for diagnosis and possible treatment referral. In genital, anal, and oral samples, HPV detection testing was performed by PCR employing the PGMY09/11 consensus primers [37], followed by typing using the Linear Array HPV genotyping test (Roche Molecular Diagnostics, CA, USA) capable of discriminating 37 a-HPV types commonly detected at the cervix [38]. It is important to highlight, that although this review focuses data regarding the male genitals, the HIM Study reported HPV infection and natural history information also for the anal canal and oral anatomical sites.

\section{HPV Genital Infection and Associated Diseases: The HIM Study}

HIM participants were recruited from September 2005 to September 2009 with a total of 4,292 men: 1,443 from Brazil, 1,426 from the United States, and 1,423 from Mexico. Furthermore, a group aged above 45 years was com- posed of about 180 men from each center [39]. Baseline analysis of this cohort revealed that genital HPV infection prevalence is higher among asymptomatic men than previously described for women [40]; HPV infection was detected in $65.2 \%$ men including $12 \%$ by HR-HPVs only, $20.7 \%$ by LR-HPVs only, $17.8 \%$ of multiple infections by HR- and LR-HPVs, and $14.7 \%$ of infections were categorized as "unclassified infection" [39] (Table 1). Particularly among virgin men, the prevalence of any and HRHPVs was 25 and $18.2 \%$ respectively [59], which points toward the transmission of infection outside of penetrative sexual intercourse and vertical transmission.

When data were analyzed separately by geographic region, HPV infection prevalence was higher among men recruited in Brazil (72.3\%) compared to that in the United States (61.3\%) and Mexico (61.9\%) [39]. HPVs 16, 51, and 59 were the most commonly detected HR-HPV types, and HPV 84, 62 and 6 were the most prevalent LR-HPVs, although some regional differences were observed regarding the distribution of viral types. Furthermore, the prevalence and incidence of the predominant diseasecausing genital HPVs infections in males (HPVs 16 and 6) were also significantly higher among men from Brazil than men from Mexico [63]. It is important to mention that solely discrete differences in the burden of genital HPV infection among MSM (men who have sex with men) and MSW (men who have sex with women) in all 3 countries analyzed were observed [57].

"Unclassified HPV" infections were more commonly detected among men recruited in the USA (20\%), as compared to Mexico (13.5\%) and Brazil (10\%), and significantly more prevalent among younger men [39]. These infections include HPV PCR-positive specimens for which hybridization to any type-specific probe was not observed. However, using a very sensible bead-based multiplex HPV genotyping methodology, a high prevalence of cutaneous $\beta$-HPVs was observed in most of these specimens $[50,54,58,62]$. The lack of association between $\beta$-HPVs DNA detection and sexual behavior variables suggested other routes of transmission of these infections such as autoinoculation $[54,58]$. Nevertheless, concordance of $\beta$-HPVs across different anatomic sites assessed was low [62], although higher across keratinized tissue sites (31.0\%; genital skin, eyebrow hairs, forearm skin) compared to mucosal sites (6.9\%; anal and oral mucosa) [60]. The clinical consequences of the presence of $\beta$-HPVs at the male genitals require further research. Of note, among HIM participants, age and blistering sunburn were significant risk factors for $\beta$-HPVs detection in normal skin swabs and eyebrow hairs [65]. 
Table 1. Main findings regarding the prevalence, incidence, and persistence of HPV infections at the male genitals in the HIM Study

\begin{tabular}{|c|c|c|}
\hline Year & Author(s) (ref) & Main findings \\
\hline 2008 & Giuliano et al. [39] & $\begin{array}{l}\text { Genital HPV prevalence was } 65.2 \% \text { ( } 12 \% \text { HR-HPVs only, } 20.7 \% \text { LR-HPVs only, } 17.8 \% \text { both } \\
\text { LR- and HR-HPVs, } 14.7 \% \text { unclassified HPV infections) } \\
\text { Multiple HPVs were detected in } 25.7 \% \text { of men } \\
\text { Genital HPV was more prevalent in Brazil than in the United States and Mexico } \\
\text { HPV prevalence was not associated to age }\end{array}$ \\
\hline 2011 & Giuliano et al. [42] & $\begin{array}{l}\text { Incidence of a new genital HPV infection was } 38.4 \text { per } 1,000 \text { person month } \\
\text { Median duration of HPV infection was } 7.5 \text { months for any-HPV and } 12.2 \text { months for HPV-16 } \\
\text { Clearance of HR-HPV infection decreased in men with a high number of lifetime female partners } \\
\text { Clearance of HR-HPV was associated to age }\end{array}$ \\
\hline 2012 & Akogbe et al. [44] & Asian/Pacific Islanders had the lowest HPV prevalence compared to Blacks and Whites \\
\hline 2012 & Repp et al. [45] & HPV prevalence was high even among those who reported always using condoms \\
\hline 2012 & Schabath et al. [46] & $\begin{array}{l}\text { Any- and HR-HPV was associated to smoking, although only evident among men reporting fewer } \\
\text { lifetime sexual partners }\end{array}$ \\
\hline 2013 & Alberts et al. [47] & $\begin{array}{l}\text { HPV detection was associated to Chlamydia trachomatis infection among men reporting } \geq 2 \text { recent } \\
\text { sexual partners } \\
\text { HPV detection was associated to HSV }-2 \text { serostatus among men reporting } 0-5 \text { lifetime sexual } \\
\text { partners }\end{array}$ \\
\hline
\end{tabular}

2013 Schabath et al. [48] HPV incidence and acquisition were lower among men of Asian/Pacific Islanders race

2013 Pierce-Campbell et al. No protective effects of condom use were observed among monogamous men

[49] The risk of HPV acquisition was twofold lower among men with no steady sex partner who always used condoms, compared with those who never used condoms

The probability of clearing an oncogenic HPV infection was $30 \%$ higher among nonmonogamous men who always used condoms

\begin{tabular}{|c|c|c|}
\hline 2013 & Sichero et al. [50] & Cutaneous $\beta$ - and $\gamma$-HPV were very prevalent at the male genitals \\
\hline 2014 & Schabath et al. [52] & HPV incidence and acquisition were higher among current smokers \\
\hline 2014 & Albero et al. [53] & $\begin{array}{l}\text { Except for specific viral types, HPV incidence and clearance was not associated to men circum- } \\
\text { cision }\end{array}$ \\
\hline 2014 & Sichero et al. [54] & $\beta$-HPV infections were not associated to any of the risk factors accessed \\
\hline 2015 & Ingles et al. [56] & Men remained susceptible to HPV infections throughout their lifespan \\
\hline 2015 & Nyitray et al. [57] & Genital HPV natural history may be similar in HIV-negative MSM and MSW \\
\hline 2016 & Nunes et al. [58] & $\beta$-HPV infection was not associated to variables regarding sexual behavior \\
\hline 2017 & Ranjeva et al. [61] & $\begin{array}{l}\text { Infection with one HPV type strongly increased the risk of infection with the same type for years } \\
\text { afterward }\end{array}$ \\
\hline
\end{tabular}


Table 1 (continued)

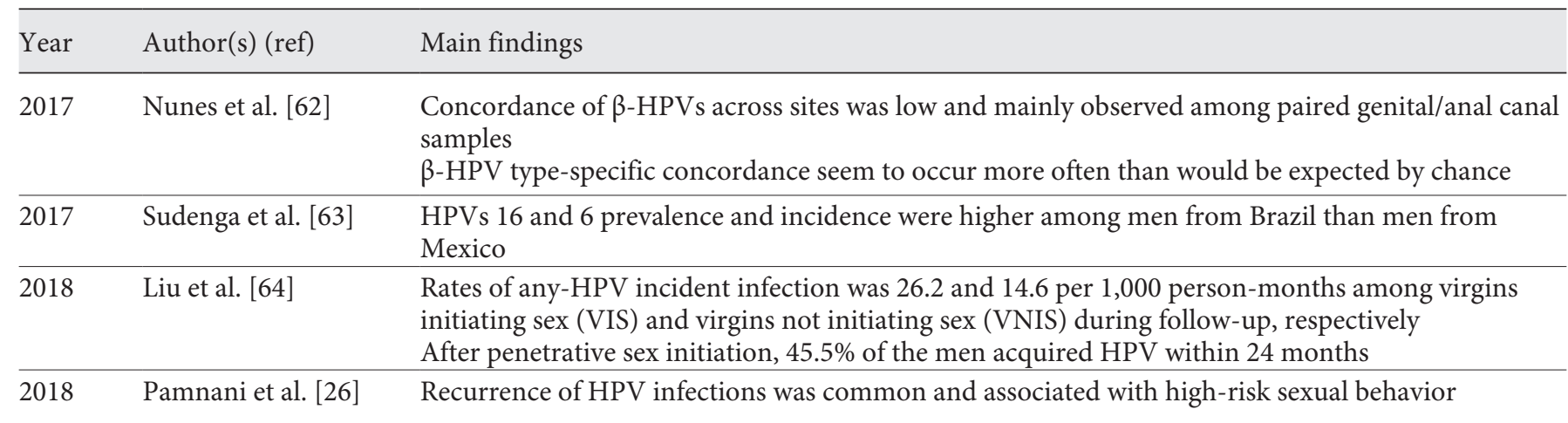

HR, high-risk; LR, low-risk; MSW, men who have sex with women; MSM, men who have sex with men; MSWM, men who have sex with women and men; HSV, herpes simplex virus; HIV, human immunodeficiency virus.

The incidence of a new HPV infection, considering a 12-month period along the HIM Study, was 38.4 per 1,000 person-months [42]. Furthermore, the 12-month cumulative incidence was similarly high among both MSM and MSW in all 3 populations studied [57]. Interestingly, for HPV-16, an initial infection increased the 1- and 2-year probability of reinfection by 20 and 14-fold respectively, in both sexually active and celibate men [61], suggesting that reinfection may originate from autoinoculation or episodic reactivation of latent virus.

Another important point regarding the natural history of HPV infection regards persistence (defined as detection of HPV DNA of a specific type at $\geq 2$ consecutive visits). Data from the HIM Study revealed that HPV infections are less prone to be persistent in men than in women: in men, the median time to clearance of any-HPV infection was 7.5 months, with 66 and $90 \%$ of infections clearing within 12 and 24 months respectively [42], and was similar between MSM and MSW [57]. In addition, it was observed that HPV-16 infections were more likely to have a longer duration, twice as long to clear compared to HPV-18 and other HPV types [42].

At each study visit, HIM participants answered an epidemiologic questionnaire that included several queries regarding sexual behavior and personal habits, which allowed for an evaluation of a number of factors associated with male genital HPV infection and persistence. HPV infection prevalence and incidence in men varied by race, with Asian/Pacific Islanders having the lowest rates compared to Blacks and Whites [41, 44, 48]. HR-HPV infection prevalence and incidence were also higher among current smokers $[46,52]$, and individuals reporting high alcohol intake [55].

HPV and the HIM Study
Regarding age, while HPV prevalence is highest among 14-24 years old women with a decrease until middle age [66], there was no clear association between age and genital HPV prevalence in men, regardless of the country examined [39]. Furthermore, the rates of detection of incident genital HPV infections [42], and the likelihood of clearing HPV types 16 and 6 infections [56], remained fairly constant across age groups. Altogether, it appears that men remain at risk for prevalent genital HPV infection across the life span, and that HPV infection and clearance may differ by gender.

A positive association between genital HPV detection in men and measures of sexual history with both maleanal and female partners, including lifetime and recent (last 3 months) number of sexual partners and sexual frequency was observed [41, 42]. Genital HPV prevalence was typically higher among MSWM (men who have sex with women and men) than among MSM or MSW for groups of HPV genotypes including LR-HPVs $(51,36$, and $42 \%$ respectively), and multiple HPV types $(37,24$, and $29 \%$ respectively) [43]. In fact, lifetime number of sexual partners was the most significant risk factor for the acquisition of genital HPV infection. The incidence rate for any-HPV infection among virgins initiating sex and virgins not initiating sex during follow up were 26.2 and 14.6 per 1,000 person-months respectively [64]. After penetrative sexual intercourse initiation, $45.5 \%$ of the men acquired HPV within 24 months. Furthermore, not only infection recurrence [26] but also HPV clearance $[42,43]$ was associated with high-risk sexual behavior.

Male circumcision was not associated with prevalence, incidence, or clearance of genital HPV detection $[51,53]$. Nevertheless, it needs to be highlighted that the use of a 
Table 2. Main findings regarding HPV-associated male genital external lesions in the HIM Study

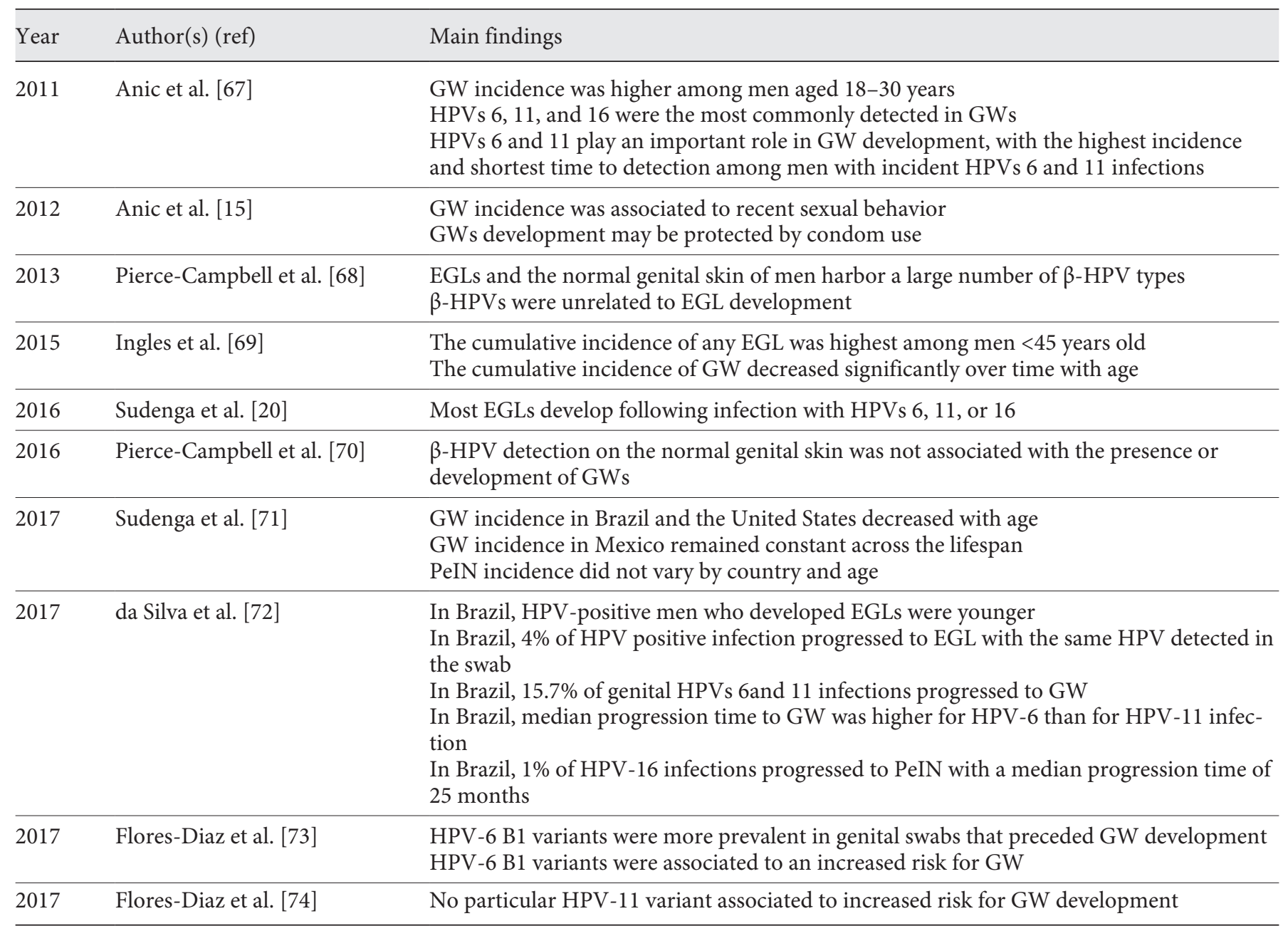

GW, genital warts; EGL, external genital lesion; PeIN, penile intraepithelial neoplasia.

single combined genital sample enclosing the penis and scrotum for HPV DNA detection in the HIM Study likely limited the ability to identify a true effect of circumcision at the glans penis, the area expected to be most likely protected by this procedure. Consistent condom use appeared to reduce HPV genital burden among high-risk men $[45,49]$. Nevertheless, HPV prevalence and persistence were high even among those who reported always using condoms, which could also be linked to the fact that in the HIM Study the combined genital sample used includes anatomical areas not covered by a condom. Finally, Chlamydia trachomatis infection and HSV-2 serostatus were also associated with prevalent genital HPV infection [47].
Approximately 5\% of the 1,788 men who had an HPV genital infection during follow-up developed an EGL (9 PeIN and 86 GWs) [20] (Table 2). Men who tested positive for HPV at baseline had nearly 12 times the risk of developing GWs [15], with highest incidence among men aged $18-30$ years $[67,69,72]$. GW incidence in Brazil and the United States decreased with age, while the incidence remained constant across the lifespan in Mexico [71]. Among HIM Study participants, 16 and $22 \%$ of genital HPV 6 and 11 infections developed into HPV 6 and 11 positive GW respectively [20]. Although HPV 6 (43.8\%) and $11(10.7 \%)$ were the most common types detected on GWs, a significant prevalence of HR-HPV types, including HPV 16 (9.8\%) was also observed in addition to coinfection of LR- and HR-HPV [67]. The median time to 
GW detection was 17.1 months; however, it was shortest among men with HPV types 6 or 11 infections (median of 7.7 months). Interestingly, while HPV-6 nucleotide variability was associated with GW development [73], there was a lack of association between any particular HPV-11 variant and increased risk of GW [74]. Recent sexual behavior was strongly associated with GW incidence, whereas frequent condom use was protective [15]. Finally, although EGLs and the normal genital skin of men harbor a large number of $\beta$-HPV types, these appear to be unrelated to EGL development in men $[68,70]$.

Among HIM participants, solely 0.5 and $2.0 \%$ of men with a genital HPV-16 infection developed an HPV16-positive PeIN within the first 12 and 24 months of follow-up respectively [20]. It was further observed that the viral type influenced the rate of progression from genital HPV infection to disease: among men who developed PeIN, in $87.5 \%$, there was more than $1 \mathrm{HR}-\mathrm{HPV}$, and 57.1\% contained HPV-16 [69]. In 1 PeIN III lesion, only HPV -6 was detected. HPV-16 infections had a relatively slow rate of progression with $50 \%$ of PeIN taking more than 19 months to be detected [20]. There were no differences by country and age for PeIN incidence $[71,72]$.

\section{Conclusions}

HPV causes considerable disease in men as well as women. At the male genitals, HPV is common although only a minority of infections progress to GW or PeIN.
Both the epidemiologic and biological relevance of HPV in penile cancer points to the importance and need for strategies to prevent benign as well as cancer and precancerous lesions of the male genitals. The quadrivalent HPV vaccine, capable of preventing women from HPV types 6, 11,16 , and 18 infections, has been shown to be also highly immunogenic in men age 16-26, and efficacious in preventing persistent genital and anal HPV infections, condyloma, and anal intraepithelial lesions [75, 76]. However, scarce information is still available to allow conclusions related to PeIN and penile cancer prevention. More research is needed to demonstrate the protective effect of the HPV vaccine on the prevention of penile cancer and precursor lesions, and protection against HPV-related oropharyngeal cancer. The HIM Study has clearly shown that men have a high HPV infection and related disease burden and that the epidemiology of these infections in men is different than what has been reported among women at the cervix. Altogether, the HIM Study data point to the benefit of gender neutral vaccination to directly benefit men as well as to more rapidly achieve population level declines in HPV infection and related diseases among both men and women.

\section{Disclosure Statement}

A.R.G. (IISP39582; IISP53280) is a current recipient of grant funding from Merck. A.R.G. and L.L.V. are members of the Merck Advisory Board for HPV prophylactic vaccines. No conflicts of interest are declared for any of the remaining authors.

\section{References}

1 Doorbar J. Host control of human papillomavirus infection and disease. Best Pract Res Clin Obstet Gynaecol. 2018 Feb;47:27-41

2 Bernard HU, Burk RD, Chen Z, van Doorslaer $\mathrm{K}$, zur Hausen $\mathrm{H}$, de Villiers EM. Classification of papillomaviruses (PVs) based on 189 PV types and proposal of taxonomic amendments. Virology. 2010 May;401(1):70-9.

3 Bouvard V, Baan R, Straif K, Grosse Y, Secre$\tan$ B, El Ghissassi F, et al.; WHO International Agency for Research on Cancer Monograph Working Group. A review of human carcinogens-Part B: biological agents. Lancet Oncol. 2009 Apr;10(4):321-2.

4 Van Doorslaer K, Bernard HU, Chen Z, de Villiers EM, zur Hausen H, Burk RD. Papillomaviruses: evolution, Linnaean taxonomy and current nomenclature. Trends Microbiol. $2011 \mathrm{Feb} ; 19(2): 49-50$
5 Okagaki T, Clark BA, Zachow KR, Twiggs LB, Ostrow RS, Pass F, et al. Presence of human papillomavirus in verrucous carcinoma (Ackerman) of the vagina. Immunocytochemical, ultrastructural, and DNA hybridization studies. Arch Pathol Lab Med. 1984 Jul;108(7): 567-70.

6 Rando RF, Lancaster WD, Han P, Lopez C. The noncoding region of HPV-6vc contains two distinct transcriptional enhancing elements. Virology. 1986 Dec;155(2):545-56.

7 Kasher MS, Roman A. Characterization of human papillomavirus type 6b DNA isolated from an invasive squamous carcinoma of the vulva. Virology. 19881 Jul;165(1):225-33.

8 Alemany L, Cubilla A, Halec G, Kasamatsu E, Quirós B, Masferrer E, et al.; HPV VVAP study group. Role of Human Papillomavirus in Penile Carcinomas Worldwide. Eur Urol. 2016 May;69(5):953-61.
9 Kitasato H, Delius H, zur Hausen H, Sorger K Rösl F, de Villiers EM. Sequence rearrangements in the upstream regulatory region of human papillomavirus type 6 : are these involved in malignant transition? J Gen Virol. 1994 May;75(Pt 5):1157-62.

10 Oft M, Böhm S, Wilczynski SP, Iftner T. Expression of the different viral mRNAs of human papilloma virus 6 in a squamous-cell carcinoma of the bladder and the cervix. Int J Cancer. 1993 Apr;53(6):924-31.

11 Wilczynski SP, Oft M, Cook N, Liao SY, Iftner T. Human papillomavirus type 6 in squamous cell carcinoma of the bladder and cervix. Hum Pathol. 1993 Jan;24(1):96-102.

12 Bercovich JA, Centeno CR, Aguilar OG, Grinstein S, Kahn T. Presence and integration of human papillomavirus type 6 in a tonsillar carcinoma. J Gen Virol. 1991 Oct;72(Pt 10): 2569-72. 
13 Diorio GJ, Giuliano AR. The Role of Human Papilloma Virus in Penile Carcinogenesis and Preneoplastic Lesions: A Potential Target for Vaccination and Treatment Strategies. Urol Clin North Am. 2016 Nov;43(4):419-25.

14 Cubilla AL, Velazquez EF, Young RH. Epithelial lesions associated with invasive penile squamous cell carcinoma: a pathologic study of 288 cases. Int J Surg Pathol. 2004t Oct; 12(4):351-64.

15 Anic GM, Lee JH, Villa LL, Lazcano-Ponce E, Gage C, José C Silva R, et al. Risk factors for incident condyloma in a multinational cohort of men: the HIM study. J Infect Dis. 2012 Mar; 205(5):789-93.

16 Hoy T, Singhal PK, Willey VJ, Insinga RP. Assessing incidence and economic burden of genital warts with data from a US commercially insured population. Curr Med Res Opin. 2009 Oct;25(10):2343-51.

17 Koshiol JE, Laurent SA, Pimenta JM. Rate and predictors of new genital warts claims and genital warts-related healthcare utilization among privately insured patients in the United States. Sex Transm Dis. 2004 Dec;31(12): 748-52.

18 Hughes G, Catchpole M, Rogers PA, Brady AR, Kinghorn G, Mercey D, et al. Comparison of risk factors for four sexually transmitted infections: results from a study of attenders at three genitourinary medicine clinics in England. Sex Transm Infect. 2000 Aug; 76(4):262-7.

19 Jin F, Prestage GP, Kippax SC, Pell CM, Donovan B, Templeton DJ, et al. Risk factors for genital and anal warts in a prospective cohort of HIV-negative homosexual men: the HIM study. Sex Transm Dis. 2007 Jul;34(7):48893.

20 Sudenga SL, Ingles DJ, Pierce Campbell CM, Lin HY, Fulp WJ, Messina JL, et al. Genital Human Papillomavirus Infection Progression to External Genital Lesions: the HIM Study. Eur Urol. 2016 Jan;69(1):166-73.

21 Chan PK, Luk AC, Luk TN, Lee KF, Cheung JL, Ho KM, et al. Distribution of human papillomavirus types in anogenital warts of men. J Clin Virol. 2009 Feb;44(2):111-4.

22 Lacey CJ. Therapy for genital human papillomavirus-related disease. J Clin Virol. 2005 Mar;32 Suppl 1:S82-90.

23 Oriel JD. Natural history of genital warts. Br J Vener Dis. 1971 Feb;47(1):1-13.

24 Steben M, Garland SM. Genital warts. Best Pract Res Clin Obstet Gynaecol. 2014 Oct; 28(7):1063-73.

25 Wiley DJ, Douglas J, Beutner K, Cox T, Fife K, Moscicki AB, et al. External genital warts: diagnosis, treatment, and prevention. Clin Infect Dis. 2002 Oct;35(s2 Suppl 2):S210-24.

26 Pamnani SJ, Sudenga SL, Rollison DE, Ingles DJ, Abrahamsen M, Villa LL, et al. Recurrence of Genital Infections With 9 Human Papillomavirus (HPV) Vaccine Types $(6,11,16,18$, $31,33,45,52$, and 58) Among Men in the HPV Infection in Men (HIM) Study. J Infect Dis. 2018 Sep 8;218(8):1219-27
27 Jeynes C, Chung MC, Challenor R. 'Shame on you'-the psychosocial impact of genital warts. Int J STD AIDS. 2009 Aug;20(8):55760.

28 Parkin DM, Bray F. Chapter 2: The burden of HPV-related cancers. Vaccine 2006;24 Suppl 3:S3/11-25.

29 Bleeker MC, Heideman DA, Snijders PJ, Horenblas S, Dillner J, Meijer CJ. Penile cancer: epidemiology, pathogenesis and prevention. World J Urol. 2009 Apr;27(2):141-50.

30 Bosch FX, Cardis E. Cancer incidence correlations: genital, urinary and some tobacco-related cancers. Int J Cancer. 1990 Aug;46(2): $178-84$.

31 Parkin DM, Almonte M, Bruni L, Clifford G, Curado MP, Piñeros M. Burden and trends of type-specific human papillomavirus infections and related diseases in the latin america and Caribbean region. Vaccine. 2008 Aug;26 Suppl 11:L1-15.

32 Hellberg D, Valentin J, Eklund T, Nilsson S. Penile cancer: is there an epidemiological role for smoking and sexual behaviour? Br Med J (Clin Res Ed). 1987 Nov;295(6609):1306-8.

33 Madsen BS, van den Brule AJ, Jensen HL, Wohlfahrt J, Frisch M. Risk factors for squamous cell carcinoma of the penis-population-based case-control study in Denmark. Cancer Epidemiol Biomarkers Prev. 2008 Oct;17(10):2683-91.

34 Diorio GJ, Leone AR, Spiess PE. Management of Penile Cancer. Urology. 2016 Oct;96:1521.

35 Rubin MA, Kleter B, Zhou M, Ayala G, Cubilla AL, Quint WG, et al. Detection and typing of human papillomavirus DNA in penile carcinoma: evidence for multiple independent pathways of penile carcinogenesis. Am J Pathol. 2001 Oct;159(4):1211-8.

36 Djajadiningrat RS, van Werkhoven E, Horenblas S. Penile cancer stage, survival and body mass index. Urol Int. 2015;94(2):220-4.

37 Gravitt PE, Peyton CL, Alessi TQ, Wheeler CM, Coutlée F, Hildesheim A, et al. Improved amplification of genital human papillomaviruses. J Clin Microbiol. 2000 Jan;38(1):35761.

38 Gravitt PE, Peyton CL, Apple RJ, Wheeler CM. Genotyping of 27 human papillomavirus types by using L 1 consensus PCR products by a single-hybridization, reverse line blot detection method. J Clin Microbiol. 1998 Oct; 36(10):3020-7.

39 Giuliano AR, Lazcano-Ponce E, Villa LL, Flores R, Salmeron J, Lee JH, et al. The human papillomavirus infection in men study: human papillomavirus prevalence and type distribution among men residing in Brazil, Mexico, and the United States. Cancer Epidemiol Biomarkers Prev. 2008 Aug;17(8):2036-43.

40 de Sanjosé S, Brotons M, Pavón MA. The natural history of human papillomavirus infection. Best Pract Res Clin Obstet Gynaecol. 2018 Feb;47:2-13.
41 Giuliano AR, Lazcano E, Villa LL, Flores R, Salmeron J, Lee JH, et al. Circumcision and sexual behavior: factors independently associated with human papillomavirus detection among men in the HIM study. Int J Cancer. 2009 Mar;124(6):1251-7.

42 Giuliano AR, Lee JH, Fulp W, Villa LL, Lazcano E, Papenfuss MR, et al. Incidence and clearance of genital human papillomavirus infection in men (HIM): a cohort study. Lancet. 2011 Mar;377(9769):932-40.

43 Nyitray AG, da Silva RJ, Baggio ML, Lu B, Smith D, Abrahamsen M, et al. The prevalence of genital HPV and factors associated with oncogenic HPV among men having sex with men and men having sex with women and men: the HIM study. Sex Transm Dis. 2011 Oct;38(10):932-40.

44 Akogbe GO, Ajidahun A, Sirak B, Anic GM, Papenfuss MR, Fulp WJ, et al. Race and prevalence of human papillomavirus infection among men residing in Brazil, Mexico and the United States. Int J Cancer. 2012 Aug; 131(3):E282-91.

45 Repp KK, Nielson CM, Fu R, Schafer S, Lazcano-Ponce E, Salmerón J, et al.; HIM study. Male human papillomavirus prevalence and association with condom use in Brazil, Mexico, and the United States. J Infect Dis. 2012 Apr;205(8):1287-93.

46 Schabath MB, Villa LL, Lazcano-Ponce E, Salmerón J, Quiterio M, Giuliano AR; HIM Study. Smoking and human papillomavirus (HPV) infection in the HPV in Men (HIM) study. Cancer Epidemiol Biomarkers Prev. 2012 Jan;21(1):102-10.

47 Alberts CJ, Schim van der Loeff MF, Papenfuss MR, da Silva RJ, Villa LL, Lazcano-Ponce $\mathrm{E}$, et al. Association of Chlamydia trachomatis infection and herpes simplex virus type 2 serostatus with genital human papillomavirus infection in men: the HPV in men study. Sex Transm Dis. 2013 Jun;40(6):508-15.

48 Schabath MB, Villa LL, Lin HY, Fulp WJ, Akogbe GO, Abrahamsen ME, et al. Racial differences in the incidence and clearance of human papilloma virus (HPV): the HPV in men (HIM) study. Cancer Epidemiol Biomarkers Prev. 2013 Oct;22(10):1762-70.

49 Pierce Campbell CM, Lin HY, Fulp W, Papenfuss MR, Salmerón JJ, Quiterio MM, et al. Consistent condom use reduces the genital human papillomavirus burden among highrisk men: the HPV infection in men study. J Infect Dis. 2013 Aug;208(3):373-84.

50 Sichero L, Pierce Campbell CM, Ferreira S, Sobrinho JS, Luiza Baggio M, Galan L, et al.; HIM Study Group. Broad HPV distribution in the genital region of men from the HPV infection in men (HIM) study. Virology. 2013 Sep;443(2):214-7.

51 Albero G, Villa LL, Lazcano-Ponce E, Fulp W, Papenfuss MR, Nyitray AG, et al. Male circumcision and prevalence of genital human papillomavirus infection in men: a multinational study. BMC Infect Dis. 2013 Jan;13(1): 18. 
52 Schabath MB, Villa LL, Lin HY, Fulp WJ, Lazcano-Ponce E, Salmerón J, et al. A prospective analysis of smoking and human papillomavirus infection among men in the HPV in Men Study. Int J Cancer. 2014 May; 134(10): 2448-57.

53 Albero G, Castellsagué X, Lin HY, Fulp W, Villa LL, Lazcano-Ponce E, et al. Male circumcision and the incidence and clearance of genital human papillomavirus (HPV) infection in men: the HPV Infection in men (HIM) cohort study. BMC Infect Dis. 2014 Feb;14(1):75.

54 Sichero L, Pierce Campbell CM, Fulp W, Ferreira S, Sobrinho JS, Baggio M, et al.; HIM Study group. High genital prevalence of cutaneous human papillomavirus DNA on male genital skin: the HPV Infection in Men Study. BMC Infect Dis. 2014 Dec;14(1):677.

55 Schabath MB, Thompson ZJ, Egan KM, Torres BN, Nguyen A, Papenfuss MR, et al. Alcohol consumption and prevalence of human papillomavirus (HPV) infection among US men in the HPV in Men (HIM) study. Sex Transm Infect. 2015 Feb;91(1):61-7.

56 Ingles DJ, Lin HY, Fulp WJ, Sudenga SL, Lu B, Schabath MB, et al. An analysis of HPV infection incidence and clearance by genotype and age in men: The HPV Infection in Men (HIM) Study. Papillomavirus Res. 2015 Dec; 1:126-35.

57 Nyitray AG, Chang M, Villa LL, Carvalho da Silva RJ, Baggio ML, Abrahamsen M, et al. The natural history of genital human papillomavirus among HIV-negative men having sex with men and men having sex with women. J Infect Dis. 2015 Jul;212(2):202-12.

58 Nunes EM, Sudenga SL, Gheit T, Tommasino M, Baggio ML, Ferreira S, et al.; HIM Study group. Diversity of beta-papillomavirus at anogenital and oral anatomic sites of men: the HIM Study. Virology. 2016 Aug;495:33-41.

59 Liu Z, Nyitray AG, Hwang LY, Swartz MD, Abrahamsen M, Lazcano-Ponce E, et al. Human Papillomavirus Prevalence Among 88 Male Virgins Residing in Brazil, Mexico, and the United States. J Infect Dis. 2016 Oct; 214(8):1188-91.
60 Hampras SS, Rollison DE, Giuliano AR, McKay-Chopin S, Minoni L, Sereday K, et al. Prevalence and Concordance of Cutaneous Beta Human Papillomavirus Infection at $\mathrm{Mu}$ cosal and Cutaneous Sites. J Infect Dis. 2017 Jul;216(1):92-6.

61 Ranjeva SL, Baskerville EB, Dukic V, Villa LL, Lazcano-Ponce E, Giuliano AR, et al. Recurring infection with ecologically distinct HPV types can explain high prevalence and diversity. Proc Natl Acad Sci USA. 2017 Dec; 114(51):13573-8.

62 Nunes EM, López RV, Sudenga SL, Gheit T, Tommasino M, Baggio ML, et al.; HIM Study group. Concordance of Beta-papillomavirus across anogenital and oral anatomic sites of men: the HIM Study. Virology. 2017 Oct;510: 55-9.

63 Sudenga SL, Torres BN, Silva R, Villa LL, Lazcano-Ponce $\mathrm{E}$, Abrahamsen $\mathrm{M}$, et al. Comparison of the Natural History of Genital HPV Infection among Men by Country: Brazil, Mexico, and the United States. Cancer Epidemiol Biomarkers Prev. 2017 Jul;26(7): 1043-52.

64 Liu Z, Nyitray AG, Hwang LY, Swartz MD, Abrahamsen M, Lazcano-Ponce E, et al. Acquisition, Persistence, and Clearance of $\mathrm{Hu}$ man Papillomavirus Infection Among Male Virgins Residing in Brazil, Mexico, and the United States. J Infect Dis. 2018 Feb;217(5): 767-76.

65 Hampras SS, Giuliano AR, Lin HY, Fisher KJ, Abrahamsen ME, Sirak BA, et al. Natural history of cutaneous human papillomavirus (HPV) infection in men: the HIM study. PLoS One. 2014 Sep;9(9):e104843.

66 Dunne EF, Unger ER, Sternberg M, McQuillan G, Swan DC, Patel SS, et al. Prevalence of HPV infection among females in the United States. JAMA. 2007 Feb;297(8):813-9.

67 Anic GM, Lee JH, Stockwell H, Rollison DE, Wu Y, Papenfuss MR, et al. Incidence and human papillomavirus (HPV) type distribution of genital warts in a multinational cohort of men: the HPV in men study. J Infect Dis. 2011 Dec;204(12):1886-92.

68 Pierce Campbell CM, Messina JL, Stoler MH, Jukic DM, Tommasino M, Gheit T, et al. Cutaneous human papillomavirus types detected on the surface of male external genital lesions: a case series within the HPV Infection in Men Study. J Clin Virol. 2013b Dec;58(4): 652-9.
69 Ingles DJ, Pierce Campbell CM, Messina JA, Stoler MH, Lin HY, Fulp WJ, et al. Human papillomavirus virus (HPV) genotype- and age-specific analyses of external genital lesions among men in the HPV Infection in Men (HIM) Study. J Infect Dis. 2015 Apr; 211(7):1060-7.

70 Pierce Campbell CM, Gheit T, Tommasino M, Lin HY, Torres BN, Messina JL, et al. Cutaneous beta human papillomaviruses and the development of male external genital lesions: A case-control study nested within the HIM Study. Virology. 2016 Oct;497:314-22.

71 Sudenga SL, Torres BN, Fulp WJ, Silva R, Villa LL, Lazcano-Ponce E, et al. Country-specific HPV-related genital disease among men residing in Brazil, Mexico and The United States: the HIM study. Int J Cancer. 2017 Jan; 140(2):337-45.

72 da Silva RJ, Sudenga SL, Sichero L, Baggio ML, Galan L, Cintra R, et al. HPV-related external genital lesions among men residing in Brazil. Braz J Infect Dis. 2017 Jul - Aug;21(4): 376-85.

73 Flores-Díaz E, Sereday KA, Ferreira S, Sirak B, Sobrinho JS, Baggio ML, et al.; HIM Study group. HPV-6 Molecular Variants Association With the Development of Genital Warts in Men: the HIM Study. J Infect Dis. 2017 Feb; 215(4):559-65.

74 Flores-Díaz E, Sereday KA, Ferreira S, Sirak B, Sobrinho IS, Baggio ML, et al.; The HIM Study Group. HPV-11 variability, persistence and progression to genital warts in men: the HIM study. J Gen Virol. 2017 Sep;98(9): 2339-42.

75 Giuliano AR, Palefsky JM, Goldstone S, Moreira ED Jr, Penny ME, Aranda C, et al. Efficacy of quadrivalent $\mathrm{HPV}$ vaccine against HPV Infection and disease in males. N Engl J Med. 2011 Feb;364(5):401-11.

76 Palefsky JM, Giuliano AR, Goldstone S, Moreira ED Jr, Aranda C, Jessen H, et al. HPV vaccine against anal HPV infection and anal intraepithelial neoplasia. N Engl J Med. 2011 Oct;365(17):1576-85. 